\title{
Decreased tyrosine kinase activity in partially purified insulin receptors from muscle of young, non-obese first degree relatives of patients with Type 2 (non-insulin-dependent) diabetes mellitus
}

\author{
A. Handberg ${ }^{1}$, A. Vaag ${ }^{2}$, J.Vinten ${ }^{1}$, H.Beck-Nielsen ${ }^{2}$ \\ ${ }^{1}$ Department of Medical Physiology, Panum Institute, University of Copenhagen, Denmark \\ ${ }^{2}$ Diabetes Research Center, Odense University Hospital, Denmark
}

Summary. Recently, we demonstrated insulin resistance due to reduced glucose storage in young relatives of Type 2 diabetic patients. To investigate whether this was associated with a defective insulin receptor kinase, we studied ten of these young ( $27 \pm 1$ years old) non-obese glucose tolerant first degree relatives of patients with Type 2 diabetes and eight matched control subjects with no family history of diabetes. Insulin sensitivity was assessed by a hyperinsulinaemic, euglycaemic clamp. Insulin receptors were partially purified from muscle biopsies obtained in the basal and the insulin-stimulated state during the clamp. Insulin binding capacity was decreased by $28 \%$ in the relatives $(p<0.05)$ in the basal biopsy. Tyrosine kinase activity in the receptor preparation was decreased by $50 \%$ in both basal and insulin-stimulated biopsies from the relatives. After stimulation with insulin "in vitro", kinase activity was reduced in the relatives in basal $(p<0.005)$ and insulin-stimulated $(p<0.01)$ biopsies and also when expressed per insulin binding capacity $(p \approx 0.05)$. Insulin stimulation of non-oxidative glucose metabolism correlated with "in vitro" insulin-stimulated tyrosine kinase activity $(r=0.61, p<0.01)$ and also when expressed per binding capacity $(r=0.53$, $p<0.025)$. We suggest that the marked defect in tyrosine kinase activity in partially purified insulin receptors from skeletal muscle is an early event in the development of insulin resistance and contributes to the pathophysiology of Type 2 diabetes.

Key words: Insulin resistance, insulin receptor, tyrosine kinase, skeletal muscle, Type 2 (non-insulin-dependent) diabetes mellitus, insulin binding.
Type 2 (non-insulin-dependent) diabetes mellitus is characterized by abnormalities in insulin secretion and by insulin resistance in target tissues [1-5]. Studies of twinpairs and pedigrees have demonstrated a strong genetic component in Type 2 diabetes [6-13], and it has been hypothesized that insulin resistance in skeletal muscle is inherited $[6,8,9,12]$. Thus, insulin resistance in the glucose storage pathway was demonstrated in obese "prediabetic" Pima Indians $[8,10,12]$ and in middle-aged, obese non-diabetic first degree relatives of patients with Type 2 diabetes [6]. Recently, we demonstrated insulin resistance in muscle of non-obese first degree relatives of Type 2 diabetic patients $20-30$ years before the probable onset of frank diabetes [14]. Events following the interaction between insulin and its receptor have been suggested to be the predominant causes of this reduced response to insulin [15-27]. In Type 2 diabetes, decreased skeletal muscle insulin receptor kinase activity has been reported [15-19]. Furthermore, impaired insulin activation of glycogen synthase in skeletal muscle from Type 2 diabetic patients $[26,28]$, and from their young, non- obese relatives [14] has been demonstrated. Finally, although the expression of the glucose transporter GLUT 4 seems normal in Type 2 diabetes [29-32], impaired activation of GLUT 4 could contribute to the pathophysiology of this disease.

Given that a defect in the skeletal muscle insulin receptor kinase has been repeatedly demonstrated in Type 2 diabetes, and that activation of the receptor kinase is necessary to trigger the intracellular effects of insulin [27] including activation of glycogen synthase [33], impaired receptor kinase activation could be crucial for the development of insulin resistance. To address this question, we have studied insulin receptor function in non-obese glucose tolerant first degree relatives of patients with Type 2 diabetes. We selected relatives under the age of 30 to establish whether a defect in insulin receptor signal transduction is present long before the possible development of diabetes. 
Table 1. Clinical characteristics of first degree relatives of patients with Type 2 diabetes and control subjects with no family history of Type 2 diabetes. Fasting glucose and insulin are the means of four determinations

\begin{tabular}{lll}
\hline & Relatives & Control subjects \\
\hline Age (years) & $27.1 \pm 0.8$ & $25.1 \pm 1.1$ \\
Sex (female/male) & $5 / 5$ & $4 / 4$ \\
Weight $(\mathrm{kg})$ & $74.3 \pm 4.8$ & $75.3 \pm 3.9$ \\
BMI $\left(\mathrm{kg} / \mathrm{m}^{2}\right)$ & $24.05 \pm 1.0$ & $24.2 \pm 0.9$ \\
$\begin{array}{l}\text { Fasting plasma glucose } \\
\text { (mmol/l) }\end{array}$ & $5.3 \pm 0.1$ & $5.3 \pm 0.1$ \\
$\begin{array}{l}\text { Fasting plasma insulin } \\
\text { (nmol/ } / \text { ) }\end{array}$ & $0.078 \pm 0.01$ & $0.056 \pm 0.01$ \\
Glycated haemoglobin $(\%)$ & $5.3 \pm 0.2$ & $5.4 \pm 0.1$ \\
\hline
\end{tabular}

Values are given as mean $\pm \mathrm{SEM} ; p=\mathrm{NS}$ for all comparisons

Table 2. Glucose disposal rates in a group of first degree relatives to patients with Type 2 diabetes and a matched control group during a euglycaemic insulin clamp

\begin{tabular}{lll}
\hline & Relatives & Control subjects \\
\hline GDR $_{\text {bss }}$ & $2.73 \pm 0.25$ & $2.42 \pm 0.08$ \\
GDR $_{\text {iss }}$ & $9.58 \pm 0.98$ & $10.18 \pm 0.54$ \\
d-GDR & $6.9 \pm 0.88$ & $7.8 \pm 0.52$ \\
\hline GDR $_{\text {bss-nonox }}$ & $1.04 \pm 0.35$ & $1.52 \pm 0.43$ \\
GDR $_{\text {iss-nonox }}$ & $5.38 \pm 0.7$ & $6.69 \pm 0.57$ \\
d-GDR $_{\text {nonox }}$ & $4.3 \pm 0.7$ & $5.6 \pm 0.48$ \\
\hline
\end{tabular}

Values are given as mean $\pm \mathrm{SEM} ; p=\mathrm{NS}$ for all comparisons. Glucose disposal rates are given in the basal steady-state $\left(G D R_{\text {bss }}\right)$ and after a 3-h insulin infusion $\left(40 \mathrm{mU} \cdot\left(\mathrm{m}^{2}\right)^{-1} \cdot \mathrm{min}^{-1}\right)\left(\mathrm{GDR}_{\mathrm{iss}}\right)$ and expressed in ( $\mathrm{mmol} \cdot \mathrm{kg}$ fat free mass $^{-1} \cdot \mathrm{min}^{-1}$ ) and as insulin stimulation of glucose disposal estimated as the difference between the two (d-GDR). Non-oxidative glucose disposal is given in the basal state $\left(G_{\text {bss-nonox }}\right)$ and the insulin-stimulated state $\left(\mathrm{GDR}_{\text {iss-nonox }}\right)$, and as the difference between the two (d-GDR nonox $)$

\section{Subjects, materials and methods}

\section{Chemicals}

Monocomponent porcine insulin, mono- ${ }^{125} \mathrm{I}-(\mathrm{Tyr}-\mathrm{A} 14)$-porcine insulin $(2 \mu \mathrm{Ci} / \mathrm{pmol})$ and insulin infused during clamp studies (Actrapid), were kindly donated by Novo-Nordisk (Bagsvaerd, Denmark). $\left[3-{ }^{3} \mathrm{H}\right]$ glucose for infusion during clamp and $\gamma^{32} \mathrm{P}$-ATP $(3000$ $\mathrm{Ci} / \mathrm{mmol}$ ) was obtained from New-England-Nuclear (Boston, Mass., USA) and Trasylol from Bayer AG (Leverkusen, FRG). Activated charcoal was from Merck (Darmstadt, FRG) and wheatgerm-agglutinin (WGA) sepharose from Pharmacia (Uppsala, Sweden). The protein assay was from Bio-Rad (Munich, FRG). All other reagents were from Sigma (St. Louis, Mo., USA).

\section{Subjects}

Ten first degree relatives of patients with Type 2 diabetes were recruited to the study. Inclusion criteria were the presence of at least two first degree relatives with Type 2 diabetes, or alternatively, the presence of one first degree relative and at least two second degree relatives with Type 2 diabetes. All participants had at least one parent with verified Type 2 diabetes, and only relatives between the age of 18 and 30 years who had normal oral glucose tolerance tests were included. They were compared with eight control subjects with normal oral glucose tolerance and with no family history of Type 2 diabetes. The subjects were randomly chosen from a larger population of relatives who participated in our previous study [14]. Table 1 illustrates the relevant clinical data of the subjects studied. The two groups were carefully matched with respect to age, sex and BMI and all participants were non-obese, normoglycaemic and had fasting plasma-insulin within the normal range. None of the subjects had clinical evidence of endocrine, cardiac, hepatic or renal diseases, nor were they taking medication known to influence glucose metabolism. The subjects were not undertaking strenuous exercise and they were instructed to avoid excessive physical exercise for at least 2 days before the study. Informed consent was obtained from all subjects and the study was approved by the regional ethical committee and was performed in accordance with the principles of the Helsinki Declaration.

\section{In vivo methods}

Euglycaemic hyperinsulinaemic clamp was performed as previously described [14]. Studies were started at 07.30 hours after a 10 -h overnight fast. After a 120 -min equilibration period for basal measurements, insulin was infused for $180 \mathrm{~min}$ at a constant rate of 40 $\mathrm{mU} \cdot\left(\mathrm{m}^{2}\right)^{-1} \cdot \mathrm{min}^{-1}$ in both relatives and control subjects. Euglycaemia was kept constant and the plasma glucose concentration was monitored in arterialized blood every 5-10 min during the clamp. Steady-state periods were defined as the last $30 \mathrm{~min}$ in the basal state and the last 30 min during insulin infusion.

Tritiated glucose. The euglycaemic clamp study was combined with a primed continuous infusion of $\left[3-{ }^{3} \mathrm{H}\right]$ glucose as previously described [14]. To ensure that isotope equilibrium was achieved, the continous infusion of $\left[3-{ }^{3} \mathrm{H}\right]$ glucose $(0.22 \mu \mathrm{Ci} / \mathrm{min})$ was begun $90-120 \mathrm{~min}$ before measurements used for calculation of glucose turnover were performed.

Indirect calorimetry was performed using a computerized, flowthrough canopy gas analyser system (Deltatrac; Datex, Helsinki, Finland) as described previously [14]). Briefly, air was suctioned at a rate of 40 litres per min through a canopy placed over the head of the subject and analysed for changes in $\mathrm{O}_{2}$ and $\mathrm{CO}_{2}$ concentrations. After an equilibration period of $10 \mathrm{~min}$, the average $\mathrm{O}_{2}$ consumption and $\mathrm{CO}_{2}$ production along with urea nitrogen excretion in the two 30 -min steady-state periods were used to calculate carbohydrate oxidation rates.

Muscle biopsies were obtained from the vastus lateralis muscle at the end of the basal and the insulin-stimulated steady-state periods using a modified Bergstrøm needle (including suction) under local anaesthesia. Before extraction of insulin receptors the muscle samples were freeze-dried and dissected free of visible connective tissue, fat and blood.

Calculations of glucose kinetics were performed as previously described [14]. During the steady-state periods, glucose turnover rates (hepatic glucose output and total peripheral glucose disposal) were calculated at 10-min intervals using Steele's equations [34]. Rates were expressed per $\mathrm{kg}$ fat free mass (FFM). Total body fat (and thus FFM) were measured using the bioimpedance method. Non-oxidative glucose disposal (glucose storage) was calculated as the difference between total glucose disposal and glucose oxidation, as determined by indirect calorimetry.

\section{In vitro methods}

Partial purification of insulin receptors. Receptors were isolated in parallel from biopsies obtained in the basal and in the insulin-stimulated state from each study subject. Whether the biopsy was obtained from the group of relatives or from the control group was not known to the technician preparing the receptors. Four receptor 
preparations were run in parallel. Insulin receptors were partially purified essentially as described by Bryer-Ash [35], with modifications. Freeze-dried muscle (15-50 mg, corresponding to around 60 $200 \mathrm{mg}$ of wet weight), was homogenized on ice with a Polytron homogenizer at maximum speed, for $2 \times 15 \mathrm{~s}$ in $5 \mathrm{ml}$ of $40 \mathrm{mmol} / 1$ Hepes, $\mathrm{pH} 7.6,1 \%$ Triton X-100 (weight/volume, w/v), $900 \mathrm{kal}-$ likrein inhibiting units (KIE) $/ \mathrm{ml}$ Trasylol, $5 \mathrm{mmol} / \mathrm{l}$ EDTA, $10 \mathrm{mmol} / \mathrm{l} \mathrm{NaF}, 10 \mathrm{mmol} / \mathrm{l} \mathrm{Na}$ pyrophosphate, $1.5 \mathrm{mg} / \mathrm{ml}$ benzamidine, $2 \mathrm{mmol} / 1$ phenylmethylsulphonyl-flouride (PMSF) and $1 \mathrm{mmol} / \mathrm{l} \mathrm{Na}$-vanadate. The homogenate was centrifuged at $8000 \times \mathrm{g}$ for $8 \mathrm{~min}, 4^{\circ} \mathrm{C}$ followed by solubilization using end-over-end rotation for $30 \mathrm{~min}$ at $4^{\circ} \mathrm{C}$. After centrifugation at $200,000 \times g$ for $60 \mathrm{~min}$, $4^{\circ} \mathrm{C}$, the supernatant was passed over a $1 \mathrm{ml}$ WGA-sepharose column three times followed by washing with $50 \mathrm{ml}$ of $40 \mathrm{mmol} / 1 \mathrm{Hepes}$, $\mathrm{pH} 7.6,0.1 \%$ Triton $\mathrm{X}-100,150 \mathrm{mmol} / 1 \mathrm{NaCl}$, and the partially purified insulin receptors were eluted in $1.5 \mathrm{ml}$ of $40 \mathrm{mmol} / / \mathrm{Hepes}, 7.6$, $150 \mathrm{mmol} / 1 \mathrm{NaCl}, 0.1 \%$ Triton $\mathrm{X}-100(\mathrm{w} / \mathrm{v})$ and $0.3 \mathrm{~mol} / 1 \mathrm{~N}-\mathrm{ace}-$ tylglucosamine. Protein concentrations of the eluates were determined according to the method of Bradford [36] using the Bio-Rad assay. PMSF ( $1 \mathrm{mmol} / \mathrm{l})$ and Trasylol $(900 \mathrm{KIE} / \mathrm{ml})$ were added and the preparations were stored at $-80^{\circ} \mathrm{C}$ until assayed. Protein recoveries after receptor purification were not different in the two groups studied $(0.41 \pm 0.035 \mu \mathrm{g} / \mathrm{mg}$ freeze-dried muscle in the relatives and $0.33 \pm 0.018 \mu \mathrm{g} / \mathrm{mg}$ muscle in the control group, NS).

Insulin binding. Fifty microlitres of WGA-eluate was incubated overnight with ${ }^{125} \mathrm{I}(\mathrm{Tyr}-\mathrm{A} 14)$-insulin $\left(3 \times 10^{-11} \mathrm{~mol} / \mathrm{l}\right.$ final $)$ with or without various concentrations of unlabelled insulin $\left(10^{-10}-10^{-6}\right.$ $\mathrm{mol} / \mathrm{l}$ final) in a buffer consisting of $25 \mathrm{mmol} / \mathrm{l}$ Hepes, $\mathrm{pH} 7.6$, $5 \mathrm{mmol} / \mathrm{l} \mathrm{MgSO}_{4}$ and $0.5 \%$ bovine serum albumin (BSA) at $4^{\circ} \mathrm{C}$. Bound and free insulin were separated using dextran-coated charcoal.

Receptor kinase activity towards poly(Glu;Tyr(4:1)). Aliquots of partially purified insulin receptors were incubated with or without increasing concentrations of insulin $\left(10^{-10}-10^{-6} \mathrm{~mol} / 1\right.$ final $)$ for $1 \mathrm{~h}$ at room temperature. Poly(Glu, Tyr $(4: 1))(1.3 \mathrm{mg} / \mathrm{ml})$ was added and after $20 \mathrm{~min}$ the phosphorylation reaction was initiated by addition of $1 \mathrm{mmol} / \mathrm{l} \mathrm{Na}$-vanadate and $50 \mu \mathrm{mol} / 1 \gamma^{32} \mathrm{P}$-ATP $(2 \mu \mathrm{Ci}$ per vial), $10 \mathrm{mmol} / 1 \mathrm{MgCl}_{2}$ and $5 \mathrm{mmol} / 1 \mathrm{MnCl}_{2}$. The reaction was stopped after 30 min by spotting aliquots on Whatman $3 \mathrm{MM}$ filter paper and precipitating in ice-cold $10 \%$ trichloroacetic acid containing $10 \mathrm{mmol} / \mathrm{l}$ Na-pyrophosphate followed by washing, drying and counting in a $\beta$-scintillation counter.

Immunofluorescence assay of insulin receptors. In order to validate the use of bound/free $(\mathrm{B} / \mathrm{F})$ ratio at tracer insulin concentration as a relative measure for insulin receptors in the preparations, insulin receptor number was also determined by use of an immunofluorescence assay in some of the preparations. After protein determination, binding, and kinase studies had been performed, immunoreactivity of receptors was determined in preparations where a sufficient amount of WGA cluate was available. A time-resolved Europium immunofluorescence assay for human insulin receptor was set up as a two-antibody sandwich reaction; $200 \mu \mathrm{l}$ titre wells (Delfia; Wallac Oy, Turku, Finland) were coated with $100 \mu$ l of a mouse monoclonal antibody directed against the C-terminus of the insulin receptor $\beta$ subunit, CT-1, [37] at a concentration of $1 \mu \mathrm{g} / \mathrm{ml}$ in potassium phosphate buffer for $1 \mathrm{~h}$ at $\mathrm{pH} 8$. The wells were emptied and blocked with a solution of $0.1 \%$ Triton $\mathrm{X}-100$ in Tris $(10 \mathrm{mmol} / \mathrm{l})$ buffered saline $(150 \mathrm{mmol} / \mathrm{l}) \mathrm{pH} 7.6$ (buffer A) and $0.5 \% \mathrm{BSA}$. The receptor preparation, diluted to $100 \mu \mathrm{l}$ in buffer $\mathrm{A}$, was added and incubated for $16 \mathrm{~h}$ at room temperature. After washing the wells six times with buffer A, $100 \mu \mathrm{l}$ of an Europium (Eu) chelate labelled $(5 \mathrm{~mol} \mathrm{Eu} / \mathrm{mol}$ antibody) monoclonal antibody directed against the $\mathrm{N}$-terminus of the insulin receptor $\alpha$-subunit, 83-14, [38] diluted to a concentration of $0.1 \mu \mathrm{g} / \mathrm{ml}$, was added. Following a 2 -h incubation, the wells were washed and after addition of Enhancement solution (Delfia; Wallac Oy), Eu fluorescence was measured in a 1232 Delfia Fluorometer (Wallac, Oy). The concentration of dilutions of insulin receptor preparations from human muscle biopsies was determined from a standard curve of known dilutions of insulin receptors purified from human placenta as previously described [39]. The receptor antibodies were generously donated by Dr. K. Siddle (Cambridge, UK).

A regression analysis of the $B / F$ ratio at tracer insulin concentrations in the preparations from different subjects, in the basal and insulin-stimulated state, on the insulin receptor concentrations determined by the assay described above gave a coefficient of correlation of $0.712, p<0.00005, n=26$. Since measurements of the variables on both axes were subject to errors, an ortogonal regression analysis provides the most correct estimation of the slope and the intercept of the regression line. Using this regression analysis, the reciprocal slope (a measure for $\left(\mathrm{Kd}+\mathrm{I}_{\text {tracer }}\right)$; where $\mathrm{Kd}$ is the equilibrium dissociation constant for insulin-receptor binding and $I_{\text {tracer }}$ is the concentration of insulin in tracer solution) gave an estimated $\mathrm{Kd}$ of $0.33 \mathrm{nmol} / \mathrm{l}$ and an intercept, not significantly different from zero, of $6 \%$ of mean $\mathrm{B} / \mathrm{F}$ ratio.

\section{Statistical analysis}

Data in the text, tables and figures are given as mean \pm SEM. Statistical significance between groups was tested with Student's $t$-test for unpaired comparisons and Pearsons rho $(r)$ for correlation analysis was employed. Comparisons of dose-response curves were performed by analysing the means of individual curves using a onesided Monte Carlo simulation test, number of runs were $10^{4}$. Statistical analysis were performed using Medstat version 2.1, programmed by Drs. H.R. Wulff and P.Schlichting, Herlev University Hospital (Herlev, Denmark).

\section{Results}

Basal and insulin-stimulated glucose uptake rates were not different in the two groups studied $(2.73 \pm 0.25$ vs $2.42 \pm 0.08$ (NS) and $9.58 \pm 0.98$ vs $10.18 \pm 0.54$ (NS), relatives vs control subjects, Table 2). The insulin-stimulated non-oxidative glucose disposal tended to be reduced in the group of relatives $(5.38 \pm 0.7$ vs $6.69 \pm 0.57, \mathrm{p} \approx 0.18$, Table 2). The concentrations of plasma insulin obtained in the insulin-stimulated steady state were identical in the two groups $(0.43 \pm 0.03$ vs $0.46 \pm 0.03 \mathrm{nmol} / 1$, NS, relatives vs control subjects).

Insulin receptor binding to partially purified receptors from muscle biopsies is illustrated in Figure 1. Mean binding to receptors purified from the biopsy obtained in the basal state is reduced in the group of relatives $(p<0.025)$ and from the Scatchard plots (Fig. 1) it appears that the reduced binding is due to a reduction of receptor number whereas binding affinity seems unchanged. The measured $\mathrm{B} / \mathrm{F}$ insulin ratio at tracer concentrations of insulin, referred to as binding capacity, was chosen as a relative measure of the total receptor number in the preparations, and in the relatives this value was reduced by $28 \%$ $(p<0.05)$. In receptors purified from the biopsy obtained during the insulin infusion, however, $B / F$ at tracer insulin concentration was the same in the two groups as were the means of the binding curves. Receptor number, determined by use of an immunofluorescence assay in some of the receptor preparations, correlated significantly with $\mathrm{B} / \mathrm{F}$ per volume WGA eluate $(r=0.71, p<0.00005$, $n=26$ ).

In WGA eluates isolated from biopsies obtained before and after "in vivo" administration of insulin, kinase 

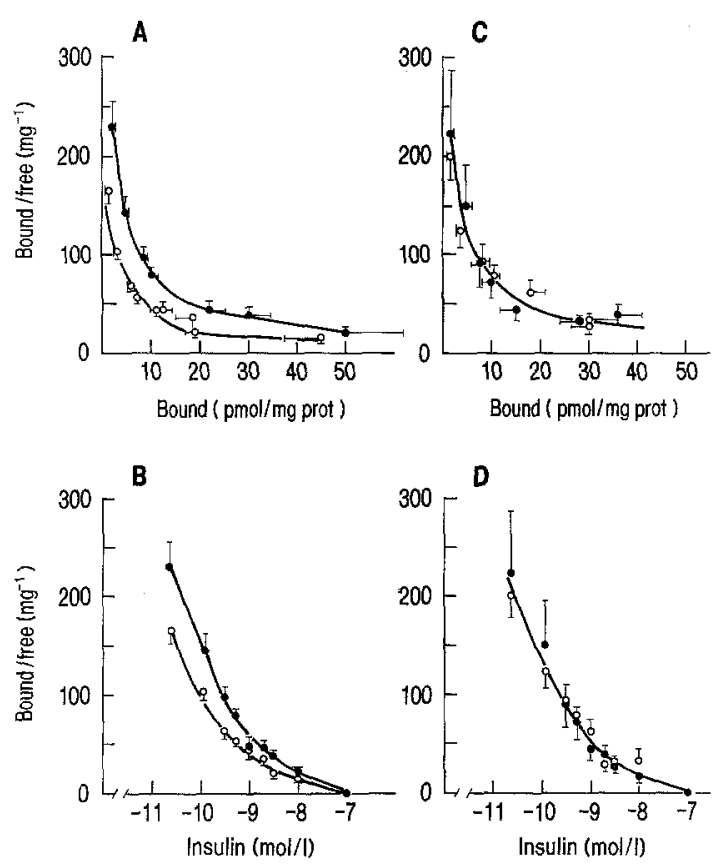

Fig. 1. (A-D) Insulin binding to partially purified insulin receptors. Insulin binding to receptors isolated from muscle biopsies obtained in the basal steady state ( $\mathbf{A}$ and $\mathbf{B}$ ) and the insulin-stimulated steady state $(\mathbf{C}$ and $\mathbf{D})$ during a hyperinsulinaemic euglycaemic clamp from relatives $(\mathbf{O})$ and control subjects $(\boldsymbol{O})$. A and $\mathbf{C}$ show Scatchard plots of binding data and in $\mathbf{B}$ and $\mathbf{D}$ data are expressed as bound/free insulin as a function of insulin concentrations in the incubation media. Binding data are expressed per $\mathrm{mg}$ of protein in the receptor preparation
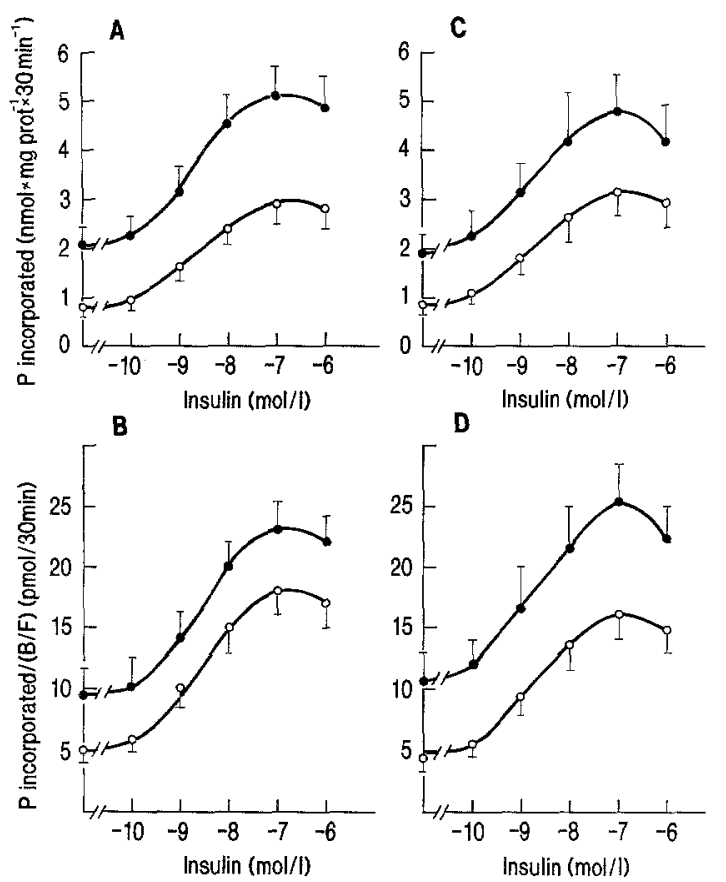

Fig. 2. (A-D) Receptor tyrosine kinase activity towards poly(Glu;Tyr(4:1)). Dose-response curves showing in vitro insulin stimulation of kinase activity expressed per $\mathrm{mg}$ of protein in the receptor preparation (A and $\mathbf{C}$ ) and per bound/free insulin at tracer insulin concentration (B and $\mathbf{D}$ ). Receptors were isolated from muscle biopsies obtained either in the basal steady state (A and $\mathbf{B}$ ) or in the insulin-stimulated steady state (C and $\mathbf{D})$ during a hyperinsulinaemic clamp from relatives $(O)$ and control subjects $(\mathbf{O})$ activity towards exogenous substrate was stimulated in a dose-dependent manner by insulin added "in vitro" in both groups (Fig. 2). The dose-response curves in the group of relatives appeared to be shifted downwards in parallel with the curves representing the control subjects. Mean receptor kinase activity expressed per $\mathrm{mg}$ of protein in the WGA eluate, was significantly reduced in the relatives, both in receptors purified from the biopsy obtained under basal conditions $(p<0.005)$ and after insulin infusion $(p<0.05)$ (Fig. 2). Likewise, mean kinase activities corrected for differences in receptor binding were reduced in the group of relatives in the basal state $(p \approx 0.05)$ (Fig. 2) and in the insulin-stimulated state $(p<0.02)$ (Fig. 2). No effect on kinase activity of insulin administered "in vivo" could be demonstrated in WGA eluates from the two groups.

Although plasma insulin tended to be elevated in the group of relatives this was not statistically significant ( $p$ $\approx 0.14$ ). In the total population of subjects, insulin binding capacity was negatively correlated with fasting plasma insulin $(r=-0.48, p<0.05$; Fig. $3 \mathrm{~A})$. Insulin-stimulated glucose disposal was correlated with "in vitro" stimulated kinase activity $(r=0.5, p<0.05 ;$ Fig. $3 \mathrm{~B})$. Insulin stimulation of the non-oxidative glucose disposal exhibited a tighter correlation with "in vitro" stimulated kinase activity per $\mathrm{mg}$ of recovered protein $(r=0.61, p<0.01$; Fig. $3 C$ ) and this correlation persisted when the kinase activity was expressed per insulin binding capacity $(r=0.53$, $p<0.025$; Fig. 3D). Furthermore, insulin stimulation of the non-oxidative glucose disposal was significantly correlated with basal tyrosine kinase activity $(r=0.53$, $p<0.025)$ and tended to be correlated with basal tyrosine kinase activity when expressed per binding capacity $(r=0.45, p<0.07)$.

\section{Discussion}

Since a strong genetic component is involved in the pathogenesis of Type 2 diabetes, a possible strategy in the attempt to identify hypothetical "primary events" contributing to the development of Type 2 diabetes is to screen healthy individuals, prone to develop the disease, for defects known to be present in overt Type 2 diabetes and involved in glucose homeostasis. This strategy has focused attention on insulin resistance in skeletal muscle. In the sequence of reactions elicited by insulin, impaired transmission of the insulin signal across the plasma membrane due to a defective insulin receptor kinase or a decreased insulin binding to its receptor have previously been suggested as factors contributing to the development of insulin resistance [15-18]. In the present study both a reduction in insulin receptor binding capacity and tyrosine kinase activity were demonstrated in young, healthy, nonobese relatives of Type 2 diabetic patients. The sub-group of relatives studied was randomly selected from a larger group [14] in which a significantly reduced insulin-stimulated glucose disposal, due to a decreased rate of non-oxidative glucose metabolism was previously demonstrated. The reduction in insulin-stimulated glucose metabolism was, however, not statistically significant in the subjects 

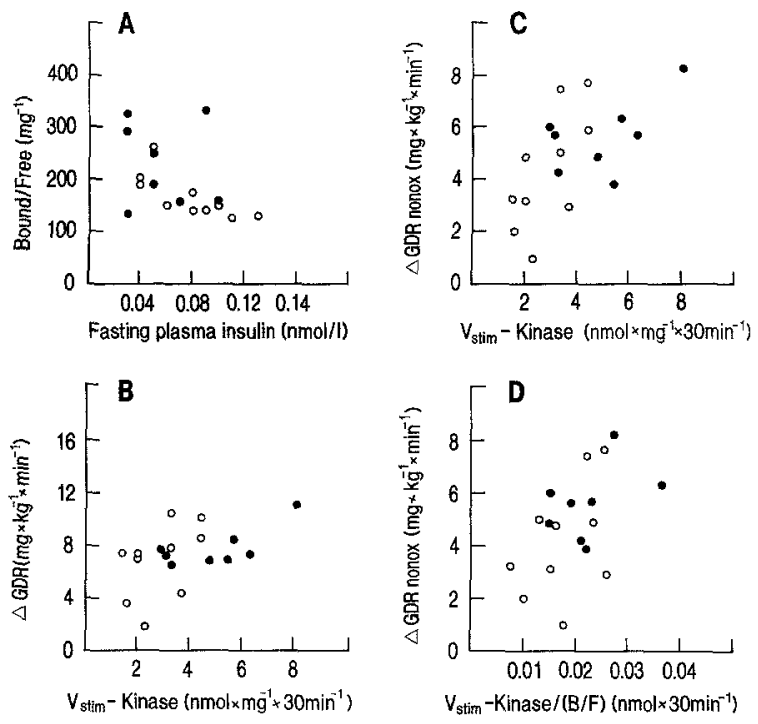

Fig.3. (A-D) Analysis of covariation. Relationship between fasting plasma insulin and bound/free insulin at tracer concentration, expressed per mg protein in the receptor preparation isolated from the muscle biopsies obtained in the basal steady state during the euglycaemic clamp (A). Receptor kinase activity, measured over a period of $30 \mathrm{~min}$, and maximally stimulated in vitro by insulin $\left(\mathrm{V}_{\mathrm{stim}}\right)$, expressed per mg of protein in the receptor preparation isolated from the basal muscle biopsy, is plotted against the difference between total glucose disposal in the basal steady state and the insulin-stimulated steady state (GDR) (B), and against the difference in non-oxidative glucose disposal $\left(\mathrm{GDR}_{\text {nonox }}\right)$ during the euglycaemic insulin clamp (C). In (D) $\left(G R_{\text {nonox }}\right)$ is plotted against $V_{\text {stim }}$ of the receptor kinase, expressed per bound/free insulin at tracer concentrations. Glucose disposal rates are expressed as $\mathrm{mg}$ glucose $\cdot \mathrm{kg}$ fat free mass $^{-1} \cdot \min ^{-1}$. Relatives are represented by $(0)$, the control group by (๑). A $r=-0.48, p<0.05 ; \quad \mathbf{B} r=0.51, p<0.05 ; \quad \mathbf{C} r=0.61$, $p<0.01 ; \mathbf{D} r=0.53, p<0.025$

participating in the present study. Because we studied a randomly selected sub-group this group is assumed to be representative, and the lack of statistical significance is considered to be due to the smaller sample size.

Our finding of a $28 \%$ reduction of receptor binding in skeletal muscle in "pre-diabetic" individuals is equivalent to results from previous studies on obese individuals [16] and Type 2 diabetic patients $[16,18]$. However, insulin binding in muscle has been reported as normal in Type 2 diabetes $[15,17,19]$. The existence of down-regulation of receptor number as a consequence of long-term exposure to insulin is generally accepted in adipocytes and some cell lines. We have demonstrated a negative correlation between receptor number and fasting insulin levels. Whether the reduced binding is primary to Type 2 diabetes or secondary to an elevated level of insulin remains unknown. Only a few studies on the short-term effect of "in vivo" insulin on binding capacity of receptors purified from skeletal muscle have been reported. Freidenburg et al. [40] demonstrated, in agreement with our finding in control subjects, no effect of insulin infusion on receptor number in healthy subjects who had no family history of diabetes. Interestingly, we demonstrated that the decreased receptor binding in the relatives was normalized after insulin infusion. This suggests that the reduced receptornumber might be overcome by an effect of insulin on transcription, post- transcriptional processing (glycation and thereby recovery) or degradation of the receptor.

In agreement with most studies on muscle receptor kinase activity in obesity, Type 2 diabetes, or both, we demonstrated a marked decrease in receptor-phosphotransferase activity [15-18]. A decreased tyrosine kinase activity in partially purified insulin receptors therefore seems to be an early event in the development of muscle insulin resistance. In vitro unstimulated kinase activities in biopsies obtained both before and following insulin infusion "in vivo" were reduced by more than $50 \%$ in the relatives in our study in agreement with the findings of Nyomba et al. [19]. The significant covariation between insulin stimulation of non-oxidative glucose disposal and "in vitro" unstimulated as well as maximally insulin-stimulated tyrosine kinase activity points to a physiological significance of this finding. The method of receptor purification involves addition of various phosphatase and kinase inhibitors, preserving the "in vivo" state of insulin receptor kinase activation induced by autophosphorylation. With respect to the spectrum of inhibitors it is comparable to the methods used in two other studies on "in vivo" receptor activity $[19,40]$. With the present rate of insulin infusion, we were not able to demonstrate ("in vivo") activation of the receptor kinase. Accordingly, in a previous study [40] kinase activation was obtained at higher plasma insulin levels.

Recently, we reported a reduced insulin activation of muscle glucose uptake and glycogen synthase in relatives [14]. Several authors have suggested that receptor autophosphorylation initiates a phosphorylation cascade which amplifies the insulin signal and causes activation of the enzymes involved in intracellular processing of glucose and activation of glucose uptake [27,33]. The presently demonstrated reduced tyrosine kinase activity could thus be the cause of the previously demonstrated reduced glycogen synthase activity [14]. Supporting the proposed key role of receptor kinase activity for stimulation of glucose uptake, we demonstrated, in contrast to [19] and in agreement with [40], a positive correlation between insulin-stimulated glucose uptake and insulin-stimulated kinase activity. The latter was also correlated with non-oxidative glucose metabolism, presumed to occur mainly in skeletal muscle. Since the reduced kinase activity is not secondary to decreased receptor binding capacity it seems likely that the major "defect" is intrinsic to the kinase. However, the gene sequences of insulin receptors from patients with Type 2 diabetes have been analysed and found to be normal [41-43], and it was concluded that insulin resistance was not due to variation in the coding sequence of the insulin receptor gene. On this basis it could be suggested that the reduced kinase activity was caused by a different phosphorylation level or pattern of the kinase. Indeed, an elevated level of phospho-tyrosine-phosphatase (PTPase) activity was recently demonstrated in Type 2 diabetic patients [25]. The decreased kinase activity in the receptor preparations from the relatives could thus be secondary to a primary defect in the regulation of PTPase activity; however, a specific insulin receptor PTPase must be isolated and studied to confirm this hypothesis. 
In a group of young individuals, genetically predisposed to develop Type 2 diabetes later in life, a markedly reduced tyrosine kinase activity was demonstrated in partially purified insulin receptors from skeletal muscle, even after correction for decreased binding capacity. We therefore suggest that a reduced insulin receptor tyrosine $\mathrm{ki}$ nase activity is an early event in the development of muscle insulin resistance and contributes to the pathophysiology of Type 2 diabetes. It is likely that the reduced kinase activity occurs as early, or even earlier than the reduction in the insulin activation of muscle glucose storage.

Acknowledgements. Ms K. Clante is gratefully thanked for excellent technical assistance. This work was supported by the Novo-Nordisk Foundation and the Danish Diabetes Association. Dr. A. Handberg is a recipient of a grant from the Novo-Foundation.

\section{References}

1. DeFronzo RA (1988) The triumvirate: $\beta$-cell, muscle, liver. A collusion responsible for NIDDM. Diabetes $37: 667-687$

2. Olefsky JM, Ciaraldi TP, Kolterman OG (1985) Mechanism of insulin resistance in non-insulin-dependent (type II) diabetes. Am J Med 79: 12-22

3. Kolterman OG, Gray RS, Bernstein J, Insel J, Scarlett JA, Olefsky JM (1981) Receptor and post receptor defects contribute to the insulin resistance in non-insulin-dependent diabetes mellitus. J Clin Invest 68: 957-969

4. Reaven GM. Chen YI, Coulston AM et al. (1983) Insulin secretion and action in non-insulin-dependent diabetes mellitus. Am J Med 75: 23-31

5. Porte D Jr (1991) Beta-cells in type II diabetes mellitus. Diabetes 40: $166-180$

6. Eriksson J, Franssila-Kallunki A, Ekstrand A et al. (1989) Early metabolic defects in persons at increased risk for non-insulin-dependent diabetes mellitus. N Engl J Med 321: 337-343

7. Warram JH, Martin BC, Krolewski AS, Soeldner JS, Kahn CR (1990) Slow glucose removal rate and hyperinsulinemia precede the development of Type 2 diabetes in offspring of diabetic patients. Ann Intern Med 113: 909-915

8. Lillioja S, Mott DM, Howard BV et al. (1988) Impaired glucose tolerance as a disorder of insulin action. Longitudinal and crosssectional studies in Pima Indians. N Engl J Med 318: 1217-1225

9. Haffner SM, Stern MP, Hazuda HP, Mitchell BD, Patterson JK (1988) Increased insulin concentrations in nondiabetic offspring of diabetic parents. N Engl J Med 319: 1297-1301

10. Saad MF, Knowler WC, Pettitt DJ, Nelson RG, Mott DM, Bennett PH (1988) The natural history of impaired glucose tolerance in the Pima Indians. N Engl J Med 319: 1500-1506

11. Newman B, Selby JV, King M-C, Slemenda C, Fabsitz R, Friedman GD (1987) Concordance for type 2 (non-insulin-dependent) diabetes mellitus in male twins. Diabetologia 30: 763-768

12. Knowler WC, Pettitt DJ, Saad MF, Bennett PH (1990) Diabetes mellitus in the Pima Indians: incidence, risk factors and pathogenesis. Diab Metab Rev 6: 1-27

13. Barnett AH, Spiliopoulos AJ, Pyke DA, Stubbs WA, Burrin J, Alberti KGMM (1981) Metabolic studies in unaffected co-twins of non-insulin dependent diabetics. BMJ 282: 1656-1658

14. Vaag A, Henriksen JE, Beck-Nielsen H (1992) Decreased insulin activation of glycogen synthase in skeletal muscle in young nonobese Caucasian first-degree relatives of patients with non-insulin-dependent diabetes mellitus. J Clin Invest 89: 782-788

15. Arner P, Pollare T, Lithell H, Livingston JN (1987) Defective insulin receptor tyrosine kinase in human skeletal muscle in obesity and type 2 (non-insulin-dependent) diabetes mellitus. Diabetologia 30: 437-440
16. Caro JF, Sinha MK, Raju SM et al. (1987) Insulin receptor kinase in human skeletal muscle from obese subjects with and without noninsulin dependent diabetes. J Clin Invest 79: 1330-1337

17. Obermaier-Kusser B, White MF, Pongratz DE et al. (1989) A defective intramolecular autoactivation cascade may cause the reduced kinase activity of the skeletal muscle insulin receptor from patients with non-insulin-dependent diabetes mellitus. J Biol Chem 264: 9497-9504

18. Maegawa H, Shigeta Y, Egawa K, Kobayashi M (1991) Impaired autophosphorylation of insulin receptors from abdominal skeletal muscles in nonobese subjects with NIDDM. Diabetes 40: 815-819

19. Nyomba BL, Ossowski VM, Bogardus C, Mott DM (1990) Insulin-sensitive tyrosine kinase: relationship with in vivo insulin action in humans. Am J Physiol 258:E964-E974

20. Brillon DJ, Freidenberg GR, Henry RR, Olefsky JM (1989) Mechanism of defective insulin-receptor kinase activity in NIDDM. Evidence of two receptor populations. Diabetes 38: 397-403

21. Freidenberg GR, Reichart D, Olefsky JM, Henry RR (1988) Reversibility of defective adipocyte insulin receptor kinase activity in non-insulin-dependent diabetes mellitus. J Clin Invest 82: 1398-1406

22. Bak JF, Smitz O, Sorensen NS, Pedersen O (1989) Postreceptor effects of sulfonylurea on skeletal muscle glycogen synthase activity in type II diabetic patients. Diabetes 38: 1343-1350

23. Scott Thies R, Molina JM, Ciaraldi TP, Freidenberg GF, Olefsky JM (1990) Insulin-receptor autophosphorylation and endogenous substrate phosphorylation in human adipocytes from control, obese, and NIDDM subjects. Diabetes 39:250-259

24. Groop LC, Saloranta C, Shank M, Bonadonna RC, Ferrannini E, DeFronzo RA (1991) The role of free fatty acid metabolism in the pathogenesis of insulin resistance in obesity and non-insulin-dependent diabetes mellitus. J Clin Endocrinol Metab 72: 96-107

25. McGuire MC, Fields RM, Nyomba BL et al. (1991) Abnormal regulation of protein tyrosine phosphatase activities in skeletal muscle of insulin-resistant humans. Diabetes 40: 939-942

26. Damsbo P, Vaag A, Hother-Nielsen O, Beck-Nielsen H (1991) Reduced glycogen synthase activity in skeletal muscle from obese patients with and without type 2 (non-insulin-dependent) diabetes mellitus. Diabetologia 34: 239-245

27. Haring HU (1991) The insulin receptor: signalling mechanism and contribution to the pathogenesis of insulin resistance. Diabetologia 34: 848-861

28. Schulman D, Rothman DL, Jue T, Stein P, DeFronzo RA, Schulman GR (1990) Quantitation of muscle glycogen synthesis in normal subjects and subjects with non-insulin dependent diabetes by ${ }^{13} \mathrm{C}$-nuclear magnetic resonance spectroscopy. $\mathrm{N}$ Engl J Med 322: 223-228

29. Handberg A, Vaag A, Damsbo P, Beck-Nielsen H, Vinten J (1990) Expression of insulin regulatable glucose transporters in skeletal muscle from type 2 (non-insulin-dependent) diabetic patients. Diabetologia 33: 625-627

30. Pedersen O, Bak JF, Andersen PH et al. (1990) Evidence against altered expression of GLUT 1 or GLUT 4 in skeletal muscle of patients with obesity or NIDDM. Diabetes 39: 865-870

31. Eriksson J, Koranyi L, Bourey R et al. (1992) Insulin resistance in type 2 (non-insulin-dependent) diabetic patients and their relatives is not associated with a defect in the expression of the insulin-responsive glucose transporter (GLUT 4) gene in human skeletal muscle. Diabetologia 35: 143-147

32. Dohm GL, Elton CW, Friedman JE et al. (1991) Decreased expression of glucose transporters in muscle from insulin-resistant patients. Am J Physiol 260:E459-E463

33. Dent $P$, Lavoinne A, Nakeilny $S$, Caudwell FB, Watt $P$, Cohen $P$ (1990) The molecular mechanism by which insulin stimulates glycogen synthesis in mammalian skeletal muscle. Nature 348: 302-308

34. Steele R (1959) Influence of glucose loading and of injected insulin on hepatic glucose output. Ann NY Acad Sci 82: 420-430 
35. Bryer-Ash M (1989) Rat insulin-receptor kinase activity correlates with in vivo insulin action. Diabetes 38: 108-116

36. Bradford M (1976) A rapid and sensitive method for the quantitation of microgram quantities of protein utilizing the principle protein-dye bonding. Anal Biochem 72: 248-254

37. Ganderton RH, Stanley KK, Field CE, Coghlan MP, Soos MA, Siddle K (1992) A monoclonal anti-peptide antibody reacting with the insulin receptor $\beta$-subunit. Biochem J 228: 195-205

38. Taylor R, Soos MA, Wells A, Argyraki M, Siddle K (1987) Insulin-like and insulin-inhibitory effects of monoclonal antibodies for different epitopes on the human insulin receptor. Biochem $\mathrm{J}$ 242: 123-129

39. Christiansen K, Tranum-Jensen J, Carlsen J, Vinten J (1991) A model for the quarternary structure of human placental insulin receptor deduced from electron microscopy. Proc Natl Acad Sci USA 88: 249-252

40. Freidenberg GR, Suter SL, Henry RR, Reichart D, Olefsky JM (1991) In vivo stimulation of the insulin receptor kinase in human skeletal muscle. Correlation with insulin-stimulated glucose disposal during euglycemic clamp studies. J Clin Invest 87: 22222229

41. Moeller DE, Yokota A, Flier JS (1989) Normal insulin receptor cDNA sequence in Pima Indians with NIDDM. Diabetes 38 : 1496-1500
42. Kusari J, Verma US, Buse JB, Henry RR, Olefsky JM (1989) Analysis of the gene sequences of the insulin receptor and the insulin-sensitive glucose transporter (GLUT 4) in patients with common-type non-insulin-dependent diabetes mellitus. J Clin Invest 88: $1323-1330$

43. Cama A, Patterson AP, Kadowaki T et al. (1990) The amino acid sequence of the insulin receptor is normal in an insulin-resistant Pima Indian. J Clin Endocrinol Metab 70: 11.55-1161

Received: 14 December 1992

and in revised form: 16 March 1993

Dr. A.Handberg

Department of Medical Physiology

Panum Institute

University of Copenhagen

Blegdamsvej 3C

DK-2200 Copenhagen

Denmark 